\title{
FERNANDO NAMORA E O NOVO CANCIONEIRO: UNS PALMOS DE TERRA NO MEIO DO PAUL
}

\section{FERNANDO NAMORA AND THE NOVO CANCIONEIRO: A FEW FEET OF LAND IN THE MIDDLE OF THE SWAMP}

\author{
Fernando Teixeira Batistal
}

\section{RESUMO}

Em Portugal, o Neorrealismo, depois de um intenso período de teorização sobre conceções de arte e literatura, no qual de digladiou com o Segundo Modernismo, afirmou-se, conquanto já tivessem sido publicadas algumas obras na segunda metade da década anterior, no início dos anos 40 do século XX. Para essa afirmação contribuiu a organização de coleções paradigmáticas do novo realismo que se defendia. O Novo Cancioneiro foi a primeira coleção, constituída por dez livros de poesia de diferentes poetas, sendo o livro de abertura, Terra, de Fernando Namora. Nestes poemas, compreende-se a conceção literária defendida pelos jovens neorrealistas e pode também reconhecer-se o exemplo humano e literário que Fernando Namora deu a toda a sua geração. Terra foi, no fundo, um livro necessário, uma pedrada no charco da revista Presença, uma porta de entrada no Neorrealismo e um cartão de visita da obra literária do seu autor.

PALAVRAS-CHAVE: Fernando Namora; Novo Cancioneiro; Neorrealismo.

\begin{abstract}
In Portugal, Neorealism, after an intense period of theorizing about conceptions of art and literature, in which it was struggled with the Second Modernism, affirmed itself, although some

1 Licenciado em Ensino de Humanidades pela Universidade Católica Portuguesa. Mestre em Educação pela Universidade do Minho. Doutorado em Literatura Portuguesa pela Faculdade de Letras da Universidade do Porto.
\end{abstract}


works had already been published in the second half of the previous decade, in the early 40s of the twentieth century. To this statement contributed the organization of paradigmatic collections of the new realism that was defended. The Novo Cancioneiro was the first collection, with ten poetry books by different poets, being the first book, Terra, by Fernando Namora. In these poems, is possible to understand the literary conception defended by the young neorealists and we can also recognize the human and literary example that Fernando Namora gave to all his generation. Terra was, in the end, a necessary book, a stone in the swamp of magazine Presença, a gateway to Neorealism, and a business card from its author's literary work.

KEYWORDS: Fernando Namora; Novo Cancioneiro; Neorealism.

Este é um livro da Terra; da Terra que não foi vista da janela do comboio. Fernando Namora

1. No início da década de 40 do século XX, em plena Grande Guerra, uma nova geração de escritores portugueses compunha uma coletânea de dez volumes de outros tantos poetas, intitulando-a Novo Cancioneiro (1941)². Era a "carta de alforria de uma geração" (TORRES, 1977, p. 83) que pretendia a afirmação de um movimento cultural cujas bases teóricas, na segunda metade da década anterior, haviam empolgado alguns jovens, estudantes universitários e não só: o neorrealismo, nome pouco consensual mas aceite na falta de melhor. Ainda que sem algumas características que os romances evidenciariam, percebe-se que, nesta poesia, já “está viva a realidade profunda da aventura neorrealista" (LOURENÇO, 1983, p. 204).

O contexto histórico internacional da época era dramático: crises económicas, desemprego e fome; implantação de regimes totalitários (nazismo naAlemanha, fascismo na Itália, franquismo na Espanha e salazarismo em Portugal); deflagração da Segunda Guerra Mundial. A arte não poderia alhear-se desta realidade. Surgiram, então, em vários pontos do mundo, movimentos culturais e artísticos que pretendiam denunciar as injustiças sociais, irmanar-se com as dores dos homens e consciencializá-los da realidade e da possibilidade de operar mudanças.

Em Portugal, a ideologia do Estado Novo impunha-se e difundia-se. À margem dela, ou em contracorrente, alguns intelectuais rebelavam-se contra uma cultura e uma arte que não reagiam ao momento que se vivia. O paul cultural do país, dominado ainda por um crepuscular modernismo, não havia superado de forma verdadeiramente significativa o primeiro momento desse movimento cultural, conquanto o Segundo Modernismo tivesse tentado - ou defendido uma revitalização literária. Os novos intelectuais, fazendo a apologia dialética da integração e superação da herança cultural, viriam a contestar sobretudo os aspetos de que discordavam dos movimentos com os quais tinham mais afinidades. Por isso, as suas atenções viraram-se sobretudo

\footnotetext{
2 Os volumes de poesia são: Terra, de Fernando Namora; Poemas, de Mário Dionísio; Sol de Agosto, de João José Cochofel; Aviso à Navegação, de Joaquim Namorado; o volume póstumo Os Poemas de Álvaro Feijó, de A. Feijó; Planície, de Manuel da Fonseca; Turismo, de Carlos de Oliveira; Passagem de Nivel, de Sidónio Muralha; Ilha de Nome Santo, de Francisco José Tenreiro e o volume póstumo Voz Que Escuta, de Políbio Gomes dos Santos.
} 
para o realismo do séc. XIX ${ }^{3}$ e para a literatura do Segundo Modernismo, pela proximidade temporal e pela sua tentativa, ainda que frágil, de superação do Primeiro Modernismo.

Com efeito, nos anos 30, ganhara prestígio no meio literário português a revista Presença, em redor da qual se tinham unido escritores e críticos de reputação consagrada com o intuito de divulgar os grandes nomes - e recentes obras - modernistas. Foi este, de facto, o alvo preferido dos novos escritores e críticos da geração neorrealista - influenciados por teóricos e escritores russos (como Plekhanov, Bukharine e Gorki), franceses (como Friedmann, Lefebvre e Gutermann) e pelos escritos que lhes chegavam de Marx e Engels ${ }^{4}$. A conferência que o jovem Alves Redol pronunciou, em 1936, com o título Arte, foi o início de uma querela sobre conceções e funções da arte que viria a prolongar-se pelos restantes anos da década e pelos anos 40 .

Defacto, os presencistas, apesar de terem verbalizado a intenção de revitalizar um verdadeiro e superior modernismo (RÉGIO, 1927, p. 1-2), acabariam por representar sobretudo, por cima desse Modernismo, "uma religação ao fluir tradicional da poesia portuguesa" (Lourenço, 1987: 162). Nas páginas da revista poderiam perceber-se características do Decadentismo, alguma abertura ao regionalismo ou folclorismo e o retomar de alguns tópicos românticos ${ }^{5}$; não as preocupações sociais de algum romantismo, mas tópicos como o locus amoenus, o bucolismo, a evasão sonhadora, o amor angelical ou o erotismo (GUIMARÃES, 1981, p. 82-84).

O lirismo presencista, género privilegiado pela Folha de Arte e Crítica, evidencia subjetivismo, individualismo e dá voz sobretudo a angustiados conflitos interiores. Marcada pelo esteticismo e pela defesa da arte-pela-arte, esta poesia de afastamento da vida social não foi só contestada pela geração neorrealista, mas também por alguns colaboradores que acabaram por se afastar da revista ${ }^{6}$.

3 O que o neorrealismo procurará recuperar do realismo oitocentista é a necessidade de ligar a literatura à sociedade, fazendo daquela um instrumento de intervenção nesta. Contudo, são diversas as raízes ideológicas (ao socialismo utópico inspirado em Proudhon opor-se-á o materialismo dialético inspirado em Marx), as preferências temáticas (enquanto o realismo oitocentista se ocupara do modo de vida e das preocupações da burguesia, o neorrealismo procurará os temas que se ligam ao proletariado e à sua condição económica: pobreza, posse de terra, opressão, conflito social, alienação...) e as técnicas literárias utilizadas (enquanto o realismo oitocentista fotografou a realidade como um facto, o neorrealismo procurava mostrar fenómenos sociais que pudessem potenciar a compreensão da essência da realidade como um todo dinâmico). A nova geração procurou dirigir-se ao povo (parecia concordar com Marx - só a luta de classes poderá conduzir a uma profunda mudança) e não à burguesia, esperando convertê-la, como haviam esperado os realistas-naturalistas do séc. XIX.

4 Apesar de já se falar em Karl Marx, em Portugal, em meados do séc. XIX, algumas obras suas só seriam traduzidas integralmente para português nos anos 70 do séc. XX. Em 1930, havia sido publicada uma biografia de Marx por Emílio Costa (cf. PITA, 2002, p. 38).

5 Gaspar Simões, um dos mais notáveis críticos ligados à revista, parece reconhecer: "à nossa época se costuma chamar, com maior ou menor verdade, neo-romântica" (1928, p. 3).

6 Alguns dos dissidentes que contestaram a bandeira da arte pela arte foram Miguel Torga, Edmundo Bettencourt e Branquinho da Fonseca, entre outros (cf. TORRES, 1977, p. 21). 
As críticas da geração neorrealista aos poetas modernistas, conquanto alguns lhes reconhecessem importância histórica, prendiam-se com o alheamento dos contextos dos novos tempos. Escrevia Fernando Namora em 1941: “O movimento presencista foi, para a sua época e enquanto correspondeu às condições e às necessidades que lhe deram origem, um movimento salutar. Mas essas condições e essas necessidades modificaram-se e o espírito presencista deixou de corresponder a qualquer coisa de vivo e de atual, cristalizou-se e... morreu" (1941, p. 285). Uma outra cultura, de novas correntes, se sobrepunha à mentalidade e às influências mais antigas. No fundo, na arte, como em todas as realidades humanas, há a considerar um duplo movimento: "des-estruturação de estruturações antigas e de estruturação de totalidades novas" (GOLDMANN, 1964, p. 338).

Apesar de os neorrealistas terem começado por promover a troca de argumentos teóricocríticos (ocorrida em periódicos da época: O Diabo, Alvorada, Seara Nova, O Globo, Sol Nascente, Gládio, Gleba, Altitude, Sintese, Pensamento, Vértice), o movimento procurou estabelecer uma estreita ligação entre teoria e praxis, nomeadamente, operacionalizando um aparelho difusor das novas obras, organizando bibliotecas, recitais de poesia, palestras em clubes e associações populares e, como referimos, editando coleções de livros (Novo Cancioneiro e Novos Prosadores) ${ }^{7}$.

A teorização neorrealista centrava-se sobretudo na expressão de novas conceções artísticas: na reivindicação de compromissos e funções sociais da arte que a geração anterior não lhe reconhecera e na utilidade por oposição à arte pela arte e ao isolamento na torre de marfim. De facto, a discussão teórica com José Régio e seus seguidores verificou-se mais ao nível de questões filosófico-ideológicas do que ao nível de procedimentos técnico-artísticos, até porque, neste último aspeto, nunca houve verdadeiramente consenso entre os neorrealistas, nem sequer nos anos iniciais, parecendo apenas consensual a necessidade de uma estética realista.

No fundo, sobre ideologias distintas, discutia-se a possibilidade de conciliar perspetivas sociais e a autonomia da arte. Para os presencistas a expressão das primeiras hipotecava a segunda; para o novo movimento, a literatura - os argumentos artísticos foram, na realidade, sobretudo literários - deveria dar voz a uma mentalidade humanista que se quis "políticoculturalmente totalizante" (PITA, 2002, p. 9) e à preocupação com os problemas económicos que se refletiam no atraso social do país.

Esta teorização foi seguida pela criação literária ${ }^{8}$. Foi neste âmbito estritamente literário que Fernando Namora colaborou com a afirmação do movimento. De facto, os livros de abertura das coletâneas Novo Cancioneiro e Novos Prosadores são da sua autoria: Terra e Fogo na

\footnotetext{
7 Esta última - de ficção narrativa - foi introduzida pelo romance Fogo na Noite Escura, de Fernando Namora (1942).

8 É de amplo consenso que o marco cronológico inicial do movimento se fixa em 1939, com a publicação de Gaibéus de Alves Redol.
} 
Noite Escura, respetivamente. Na realidade, após a publicação de Terra, ${ }^{9}$ o autor dedicar-se-á sobretudo ao romance, vindo a publicar apenas mais dois livros de poesia: Marketing (1969) e Nome para Uma Casa (1984).

2. O neorrealismo, de conceção materialista e dialética, reconhecia aos intelectuais uma função social, pois, para eles, estrutura e superstrutura sociais evoluem em interação constante: "os homens, quando têm a consciência do processo dialético da realidade, podem apressá-lo, pela ação esclarecida" (SOARES, 1947, p. 55). Deste modo, para esta geração, como expressava Joaquim Namorado, "uma arte desligada do real, moída nas torres de marfim, a atitude da política do espírito, neutra e esterilizante, de nenhum modo correspondem aos seus interesses, às suas esperanças, à sua luta. Esta é a gente de Fogo na Noite Escura". Citando o primeiro livro da coleção Novos Prosadores, acrescentava ainda: "Este livro (Fogo na Noite Escura de Fernando Namora) constitui um testemunho vivo da inquietação, das preocupações, dos problemas, das ideias e das intenções, da vida, da chamada (por comodidade e impropriamente) geração de quarenta”. (NAMORADO, 1994, p. 278). De facto, nele Fernando Namora recriava literariamente o período teórico de afirmação do neorrealismo, dando protagonismo a um grupo de estudantes que defendia novas conceções literárias, inserido na academia conimbricense em lutas socioculturais e políticas internas, expondo, na realidade, todo um Portugal atrasado, conservador e fascista. Este contributo literário para afirmação de uma divergência em relação ao modernismo presencista é percetível em qualquer dos livros de Namora inseridos nas referidas coleções dos novos escritores, tanto na poética como na narrativa.

Centrando-nos na coleção poética e no livro Terra, refira-se que este longo poema dotará o então jovem movimento neorrealista do seu manifesto poético. Reconheciam-no presencistas ${ }^{10}$ e neorrealistas. Terra era até então "o mais típico exemplar neorrealista da sua obra de poeta" (SIMÕES, 1960, p. 256). Comparado com a poesia que à época se vinha escrevendo em Portugal, este volume é - e pretendeu sê-lo - uma "pedrada no charco da Presença" (NAMORADO, 1994, p. 276-277).

O percurso do presencismo ao neorrealismo marca, com efeito, a obra inicial de Namora, que ascende do homem solitário e voltado para si, do subjetivismo presencista, visível em Relevos (1938), passando pelo ainda homem introspetivo de Mar de Sargaços (1940), até ao homem inserido numa comunidade, expresso, em Terra (1941), num dolorido realismo. Neste sentido, "abandonando os secretos e egóticos caminhos da devassa do eu, que ao modo presencista trilhara, enveredou pelos sulcos que a estética do neorrealismo lhe abria” (BELCHIOR, 1980, p. 190).

9 Antes de Terra, havia publicado Relevos e Mar de Sargaços, os quais reeditaria mais tarde num só volumes: As Frias Madrugadas.

10 Na Presença colaboraram assiduamente nomes como José Régio, João Gaspar Simões, Branquinho da Fonseca, Adolfo Casais Monteiro, Edmundo de Bettencourt, Carlos Queiroz, Saul Dias, entre outros. 
Em Relevos, encontra-se ainda a conceção do poeta como um ser "destinado a um futuro infeliz, a um desencontro com os homens, a uma biografia adversa, ou a um Fado catastrófico, infausto, desventuroso, atribulado" (TORRES, 1989, p. 15); percebe-se a introspeção e o isolamento, característicos da poesia da Presença, com a qual Namora chegou a colaborar através da publicação de alguns poemas. No entanto, como o próprio viria a afirmar, dava voz a "alguma coisa que já não cabia no espírito presencista" (NAMORA, 1941, p. 285), pois percebe-se um olhar para a realidade exterior e um desejo de despertar as consciências para as ultrajantes injustiças sociais, ainda que uma má consciência pareça assolar o poeta, pois percebe que se afasta da missão terrena a cumprir, atraiçoando-a (TORRES, 1989, p. 16). Em Mar de Sargaços, a rutura com tendências anteriores é mais percetível e o poeta vai definitivamente ao encontro do Mundo e da Vida dos Outros.

Solidário intelectualmente com a vida dos homens, enceta uma incursão num lirismo consciente, vem para a Terra, para o seu tempo, para o aqui e o agora, vem para o mundo que o preocupava. Alexandre Pinheiro Torres, no prefácio ao Novo Cancioneiro, afirma: o autor abre "um caminho todo novo para a aristocratizante poesia deste século" (1989, p. 33). O próprio Namora afirmou no ano da sua publicação: "Terra é o primeiro fruto duma orientação nova" (1941, p. 285). Esta orientação, reflexo de uma nova perspetiva ideológica, impregnava a arte de uma função de transformação sociocultural. Ainda que algumas críticas tenham sido feitas às características que a poesia neorrealista assumiu na sua fase inicial (monotonia de temas, ambientes e processos; privilégio concedido à classe dos camponeses; estandardização de personagens; exposição ideológica; afastamento de valores estéticos) $)^{11}$, elas devem ser vistas como uma necessidade histórica e como luta e oposição à poesia modernista ${ }^{12}$.

É neste livro que Fernando Namora começa a abordar a temática rural, que será retomada em Casa da Malta (1945) e persistirá nos anos seguintes em Minas de San Francisco (1946), Retalhos da Vida de Um Médico (1949), A Noite e a Madrugada (1950) e O Trigo e o Joio (1954). A paradigmática opção pelo meio rural pode associar-se à sentida necessidade de se integrar nas urgências do seu tempo e de ir ao encontro do povo (NAMORA, 1990, p. 17). No entanto, para isso, o escritor não tem de deixar de projetar a sua autenticidade biográfica. De facto, quando publica Terra, ainda se encontra a estudar em Coimbra, conquanto continue a visitar (e a recordar) a terra da infância, Condeixa, e a terra dos pais, a aldeia de Vale Florido. Na verdade, depois de Fogo na Noite Escura (escrito enquanto estudante em Coimbra, que será o ambiente de fundo do romance, como já referimos), a ruralidade marcará presença na obra namoriana, na segunda metade dos anos 40 e no início da década de 50 (quando o médico se transfere para a capital do país), enquanto o escritor exerce medicina no interior

11 O Próprio Fernando Namora viria a reconhecer a pertinência destas críticas: "nenhum escritor neorrealista nega o que há de razoável em alguns destes reparos" (1991, p. 210).

12 Segundo José Gomes Ferreira, uma das grandes novidades da poesia neorrealista foi "a tentativa de substituição das bases filosóficas tradicionais da poesia portuguesa (dualista, platónica, cristã...) pelo materialismo dialético" (1966, p. 165). 
rural de Portugal: Beira Interior e Alentejo. Neste sentido, é significativa, na obra do escritor, uma "peculiar modalidade de autobiografia" (PITA, 2002, p. 83) o que lhe possibilitará uma identificação genuína com as suas personagens ${ }^{13}$.

3. Evidenciada desde logo neste pequeno livro de poesia, na obra de Namora encontrarse-á sempre uma autenticidade da qual o romancista não abdicará na sua ficção narrativa. Aliás, a busca da face verdadeira para além das máscaras tornar-se-á mesmo uma das temáticas nucleares da sua obra.

Desde logo, o título do livro - Terra - veicula, como observa Carlos Reis, "uma marca de concreto e imediato que desde logo desmotiva leituras eventualmente interessadas em formulações simbólicas ou metafóricas" (REIS, 1983, p. 404). Também não apresenta o idílico e romântico campo, mas a terra cultivada pelo trabalho do homem. As conotações são distintas. Na realidade, para o povo que tira do solo os recursos de que vive, a terra não é um objeto de contemplação, mas um espaço económico (CHALENDAR, 1979, p. 47).

Neste sentido, o poema de abertura do Novo Cancioneiro pode ser perspetivado como o paradigma da literatura rural neorrealista. O prisma como o poeta olha para o espaço exterior rural, e anunciado no título, é explicitado na nota introdutória: "Este é um livro da Terra; da Terra que não foi vista da janela do comboio. Nem é, tão-pouco, um livro de escola. Apenas uma contribuição sincera para o conhecimento da Gleba" $(1989 \text {, p. 99) })^{14}$. O vocábulo gleba veicula conotações sociais (servos da gleba), sugerindo a opressão sofrida pelo povo e o estado arcaico das relações sociais. A ideia de contribuição para o conhecimento esclarece a conceção que subjaz a esta poesia.

Interessante também é, como dissemos, o recurso a uma palavra cara ao poeta: sinceridade (autenticidade vivencial / honestidade intelectual), cujo sentido o poeta parece distanciar da ideia romântica - e defendida pelos presencistas - de autêntica sinceridade (que confrontavam com o fingimento). Saliente-se ainda a expressão de uma rejeição de escola, num momento em

13 Segundo Casais Monteiro - crítico presencista que, como outros colaboradores da mesma revista, procurara demonstrar que as teses sociológicas dos neorrealistas menorizavam a literatura -, a opção pelo rural deve-se apenas à facilidade de demonstração de teses: "a cidade assustou os neorrealistas (...). Ali, não lhes pareceu fácil meter os destinos dos homens na arquitetura rigorosa das leis sociais, harmonizar ciência e experiência. Era pois fatal o recurso ao camponês, graças ao qual lhes parecia mais fácil pôr a lei em equação" (1950, p. 202).

14 Esta nota é suprimida na reedição dos poemas no livro As Frias Madrugadas de 1959; como refere Carlos Reis, esta eliminação, num tempo em que se tornava já desnecessário ao escritor esclarecer, com alguma carga de didatismo, o objeto preciso das suas reflexões poéticas, é significativa (1983, p. 405). Interessantes também parecem-nos as palavras de Mário Dionísio - que também introduzira uma nota no seu volume do Novo Cancioneiro -, na reedição de seus poemas, quando vem a manifestar a sua posição "antiprefácio", encarando, então, os prefácios como algo que se destina a "instalar habilidosamente o leitor num estado artificial de pré-aceitação, a diminuir-lhe as capacidades de recusa por que toda a verdadeira aceitação começa, a preparar um clima que os poemas que vai ler, e só eles, deverão criar" (s/d, p. 16). 
que a acusação de literatura enformada por teses de escola era muito frequente por parte dos delatores do neorrealismo.

O livro narra o percurso de um casal de trabalhadores da terra, expondo também o ambiente que os molda. António (cuja infância conhecemos - poema 4) e Cassilda apaixonamse (poema 5), casam (poema 12), têm um filho (poema 18), veem morrer-lhes um animal que em vida os alimenta (poema 23), lamentam que a terra não produza e emigram (poema 24). Estes poemas "são quase relatos, em que a sobriedade dos dados faz avultar o vigor das situações" (BELCHIOR, 1980, p. 190). Estes poemas (sem títulos), apresentados por numeração crescente, a qual deixa transparecer uma relação sequencial, um processo de desenvolvimento e uma unidade (inclusivamente de espaço e tempo), sugerem também um pendor narrativo, que, com efeito, tanto a obra futura de Namora como a de muitos outros neorrealistas do seu tempo teriam.

O livro conjuga, de facto, a herança romântica e regionalista com o desejo de consciencialização do neorrealismo. Expressa, de facto, um "regionalismo sem regionalismos". (FERREIRA, 1992, p. 133). Expõe mais as misérias do povo do que as suas virtudes, que haviam sido realçadas pela tendência romântica. Com efeito, Namora, assim, rejeita o "alçapão da a-historicidade, ou do mundo asséptico, sem contágio, onde o camponês tivesse o seu paraíso..." (TORRES, 1989, p. 32). Não apresenta a tranquilidade do campo vista por quem o visita, mas a dificuldade dos homens que vivem e trabalham a terra, os quais, certamente, não são apenas vistos pelo leitor como contraste aos homens da cidade, mas também como contraste a quem vive comodamente sem precisar de esforço e trabalho ${ }^{15}$.

No livro, as personagens-tipo (numa perspetiva behaviorista: veem-se os atos, os gestos e ouvem-se as palavras, sem grandes comentários sobre o seu interior) ${ }^{16}$ são ideologicamente relevantes. Em literatura, o tipo apresenta capacidade de síntese e relaciona-se com a metodologia dialética. Como considerava Campos Lima, aquele afirma-se como "a imagem da superação dos contrários particular-geral, ou concreto-abstrato. Nela espelham-se, fundidas, a representação de um indivíduo singular e a do tipo humano a que esse indivíduo pertence" (1957, p. 355). O que Namora e os neorrealistas visavam era atingir a essência da realidade pela representação do tipo, formando, através de força criadora, um particular a partir do singular ${ }^{17}$. Em Terra, predomina, com efeito, o trabalhador rural, o "Camponês de Portugal, que, mal nascido, já está

\footnotetext{
15 As palavras de Mário Dionísio, na sua Autobiografia, sobre a opção dos neorrealistas pelos camponeses em detrimento dos operários, relacionando-a com a censura, são explícitas: "a censura tinha os olhos bem abertos para o que se referisse aos operários. Os problemas que os operários suscitavam tornavam-nos mais difíceis (perigosos) de tratar" (1987, p. 32).

16 Esta era uma estratégia literária que Manuel Campos Lima defendia, em 1938, com vista à objetividade do romance $(1938$, p. 4).

17 Importa recordar estes conceitos com palavras de Lukács: "A particularidade é usada em filosofia como sinónimo de determinado; ela, com relação ao singular, representa uma universalidade relativa, e, com relação ao universal, uma singularidade relativa" (1978, p. 117).
} 
condenado a uma velhice de fome, abandono, solidão, ou a ser expulso da sua terra, invocando debalde um Deus sempre ausente" (TORRES, 1989, p. 32).

Condicionantes deste homem são a paisagem, o clima e os animais, que estão em estreita ligação com ele (poemas 4, 12, 18, 19, 22, 23 e 24). Esta aproximação ao animal sugere, de facto, a alienação do homem e a sua bestialização. O trabalho da terra, dependente por vezes dos animais (poema 23), relaciona-se também com o devir das estações e com as condições atmosféricas, as quais se aliam frequentemente às forças sociais tornando-se também forças opressoras, vitimando (último poema) os que dependem do seu trabalho para sobreviver.

4. No livro, a expressão da realidade social, económica e cultural subordina outras temáticas, não obstante estas terem também alguma visibilidade. As personagens apresentadas no poema, nomeadamente o homem e a mulher que o protagonizam, são impelidas a uma existência terra-a-terra. O amor, por exemplo, quando referido, é subordinado a fatores socioeconómicos: o poeta aconselha Cassilda a seguir o seu amor com vista a garantir um amparo forte e querido na fragilidade dos seus dias ${ }^{18}$ (poema 5); aconselha-a também, quando estiver gasta pelas agruras da vida, a beijar-lhe, ainda assim, a testa suada do marido, se ainda souber (poema 22) ${ }^{19}$.

$\mathrm{Na}$ verdade, o elemento amoroso é diretamente secundarizado nestes poemas. Com efeito, quase não temos a presença de sentimentos amorosos. Este tema não era, então, muito significativo para a mensagem neorrealista, senão para demonstrar que as dificuldades e as injustiças que atingiam os mais necessitados se sobrepunham e impediam vivências realizadas e felizes. $\mathrm{O}$ contexto histórico e a realidade social impunham outras preferências temáticas, que pareciam aos neorrealistas mais urgentes e, direta ou indiretamente, mais condicionantes da felicidade dos homens. Mais tarde, a partir dos anos 60, este tema ganharia outra dimensão na obra de Namora (nomeadamente em Cidade Solitária, Domingo à Tarde, Os Clandestinos, Resposta a Matilde e $O$ Rio Triste).

Nesta poesia namoriana, a procura de consciência de diversas privações que afetam o homem, bem como do seu contexto, assume-se como essência poética. Transmitir a um povo mais condenado a sofrer uma desgraça irremediável do que vocacionado para a luta (MARTELO, 1996, p. 120) efeitos emotivos de um conhecimento sobre a sua situação de vida constituía um objetivo. Percebe-se no livro que o poeta reconhecia a perceção de fatalidade dos populares em relação ao seu estado. A função social da literatura reivindicada pelos neorrealistas prende-se, de facto, com este fator, que Carlos Reis bem observa: "ao Neorrealismo competiria precisamente tentar transmitir às figuras que povoam o cenário rural em causa uma consciência de classe que elas não possuíam" (1983, p. 168).

\footnotetext{
18 "Terás um amparo forte na incerteza dos teus dias" (NAMORA, 1990a, p. 181).

19 "Leva ao monte o almoço do teu homem / e beija-lhe a testa gretada / se ainda souberes!" (NAMORA, 1990a, p. 199).
} 
Compreende-se que o homem da terra sente que não podia esperar muito mais do que a sua trágica solidão, um tema, aliás, que, sendo já visível nesta poesia e persistindo na ficção de fundo rural que se seguiria, o autor enriquecerá nas obras de fundo urbano. Em algumas destas, a par da solidão, encontrar-se-á a esperanç $\mathrm{a}^{20}$. Na poesia de Terra, a solidão obnubila a esperança. Aliás, solitariamente, não poderia haver qualquer esperança. Ficava subjacente que um eventual devir desejável não poderia passar pela solução dos problemas de um indivíduo, mas pela solução dos problemas da coletividade (SACRAMENTO, 1968, p. 61). Seria aqui na terra (não se refugiando em transcendências) e lá na terra (recusando migrações geográficas) que aos homens deveria ser possível a plena realização, vendo superados os constrangimentos existentes.

Neste sentido, compreende-se que, nas obras neorrealistas, a emigração seja perspetivada tendencialmente como uma forma de escape anti-heroica e individual para uma situação que afeta todos os trabalhadores. É este o único escape possível que se apresenta a António e Cassilda. A impotência perante todas as forças opressoras leva os heróis a deixar a sua terra.

Será significativo que a voz poética do livro, que quase abandona o $e u^{21}$, procurando articular a sua voz com a tragédia dos outros ${ }^{22}$, tenda claramente para o nós, o todos, a multidão (MOURÃO-FERREIRA, 1988, p. 16). No entanto, não obstante esta enunciação, ao contar o sofrimento dos homens da terra, o poeta permite que se sintam os seus líricos sentimentos. Assim, objetividade e subjetividade, realidade e individualidade não se afastam, e as características essenciais do género lírico não se apagam ${ }^{23}$. Não se trata tanto, de facto, da reprodução objetiva da realidade como da criação de efeitos no leitor de sensações análogas às sentidas pelo autor.

Poderá relacionar-se com esta conceção a seguinte frase de Fernando Namora: "fazer amar o que ele próprio ama, eis a vocação irresistível do escritor" (1990b, p. 24). No neorrealismo dos anos 40, encontra-se frequentemente uma atitude de compadecimento do escritor pelas suas personagens.... de compadecimento e de revolta pela vida que levam, o que motiva o desejo de desalienação popular e não é compatível com a resignação religiosa.

20 Álvaro Salema considera a solidão, na obra de Namora, como "a sua unidade psicológica essencial" e a esperança, ainda que "profunda, ténue, ilusória" como "a outra grande companheira do homem (1981, p. 149-154).

$21 \mathrm{Na}$ verdade, nestes poemas, encontram-se diversas vozes de enunciação poética - a voz oscila entre uma primeira pessoa de participação direta (apenas expressa no poema 6), a assimilação de uma voz coletiva e a adoção, em muitas composições, de uma atitude de observador exterior aos eventos -, contudo a voz coral sente-se transversalmente.

22 Rosa Maria Martelo refere-se a Terra como "o caso mais radical de apagamento do sujeito no Novo Cancioneiro" (1996, p. 120).

23 Taborda de Vasconcelos viria a constatar, em 1972, na já então vasta obra de Namora: "Narrando o que ia vivendo, e fundindo os resultados dessa observação com o lirismo implícito à visão pessoal das coisas, nunca lhe interessou reproduzir, exata ou fielmente, a realidade, mas assentar nela as traves do edifício literário, de modo a insinuar nos outros a convicção do que, juntos, sentiam e experimentavam" (1972, p. 23). 
Em Terra, a crença religiosa não é perspetivada de forma distinta daquela que predominará no neorrealismo em geral, é vista como um sentimentalismo arracional a que se entrega o homem rústico: "um cativeiro, uma forma de sequestro, a plataforma ao serviço dos poderosos para que os humildes por ela e com ela se sentissem recompensados de toda a servidão, sem mais nada exigirem do mundo concreto, reservado que tinham para eles as mansões celestiais, ou seja, os palácios futuros dos pobres" (TORRES, 1989, p. 30). No livro, as referências ao Deus do catolicismo são invariavelmente irónicas; percebe-se uma ironia que se sente mais trágica do que cómica.

$\mathrm{Na}$ realidade, não obstante o desejo de desalienação, neste volume de poesia, como noutros livros de Namora, não tem visibilidade a figura do revolucionário ideal - de que falava Karl Marx (FERREIRA, 1992, p. 106) -, o qual tornaria decerto a mensagem ideológica mais explícita. Contudo, o autor não buscava - muito menos buscará mais tarde - uma escrita que se pudesse aproximar da clareza panfletária de exposições de teses, críticas que os delatores do movimento neorrealista muito enfatizaram.

5. No livro, Fernando Namora recria a vida do trabalhador rural pautada por diversos condicionalismos e iniquidades socioeconómicas. Ao trazer a terra, que bem conhece, para a poesia, reativa a vertente social da poesia oitocentista, distanciando-se do Modernismo. De facto, é possível perceber nestes poemas, à semelhança de muitas outras obras da geração neorrealista (ainda que com níveis de clareza distintos), um desejo de ver superadas as privações a que estava sujeito o povo português, sem que, todavia, seja defendida ou explicitada qualquer ideologia económico-política. Este desígnio, assumindo que a arte poderia dar um contributo para a mudança, ou melhor, para que esta fosse desejada, pressupunha o reconhecimento de uma função social da literatura, o que condicionaria, inevitavelmente, as opções a tomar relativamente às formas artísticas que as obras assumiriam, embora não tivessem de ser enformadas por uma forma ortodoxa pré-definida teoricamente.

Desta forma, procurando promover o conhecimento, a desalienação ou consciencialização social do povo, Namora privilegiou uma linguagem semântico-pragmática em detrimento de uma linguagem motivada ou de intensidade (rítmica, redundante, sintética ou sugestiva). Esta opção pela sobreposição do significado ao significante e pela minimização da ambiguidade, bastante generalizável, aliás, ao movimento neorrealista ${ }^{24}$, levou alguns críticos a falar em hipóteses de renovação estética minadas, pelo bloqueio da criatividade artística individual a que se sujeitaram alguns neorrealistas dos anos 40 (PETROV, 1996, p. 73).

Na verdade, o movimento reconheceu o dilema de conjugar estética e função literárias, que cada escritor foi solucionando à sua maneira. Carlos Reis explicita assim os dois eixos: "por um lado, a dinâmica intrínseca do lirismo e da representação poética, sem a qual a própria condição

24 Eduardo Lourenço fala numa espécie de grau zero da ambiguidade que caracteriza um período de excesso de sentido (1983, p. 211). 
lírica do discurso poderia ser posta em causa; por outro lado, as linhas de força do movimento neorrealista, acentuadamente dominadas, como se sabe, por intuitos de projeção sociocultural" (1983, p. 100). A subvalorização de um desses componentes, em relação ao outro, prendia-se com a conceção de poesia e com a função e o efeito comunicativo que o poeta, efetivamente, lhe reservava. Deste modo, compreende-se que, no seio do neorrealismo, se encontrem duas atitudes estético-literárias significativamente distintas, como diferencia António Pedro Pita: "entre o espelho (o reflexo) que devolve uma imagem que se trata de reconhecer e a árvore que mergulha as suas raízes na profundidade obscura, o neorrealismo traçou múltiplas vias de uma politização necessária" (2002, p. 241) ${ }^{25}$. A opção por uma destas vias era, pois, motivada ou por não se querer abrir mão do pragmatismo da mensagem ou por não se querer prescindir da qualidade estética da obra ${ }^{26}$.

O desejo e a dificuldade de conciliar estas vertentes eram reconhecidos, teoricamente, nos anos que precederam o Novo Cancioneiro. Em 1937, podia ler-se na Sol Nascente: “A poesia é síntese. Não é nem a música, nem a imagem, nem a ideia; ela é ao mesmo tempo tudo isso. Se se procura a sua pura essência, creio bem que só aí a poderemos encontrar: pura forma ou pura síntese"; lê-se, no entanto, no mesmo texto, um pouco mais adiante: "O seu poder de síntese naufraga em sua grandiosa tarefa" (FILIPE, 1937, p. 6). Com efeito, devido ao pragmatismo desejado e à intenção de distanciamento do que o modernismo vinha produzindo, o neorrealismo concebeu uma "poesia bem mais de ideias e sentimentos do que de sons" (RODRIGUES, 1988, p. 9). O Novo Cancioneiro, e desde logo o livro de Fernando Namora, rejeitam qualquer tentativa de perfeição formal que pudesse resultar em mero esteticismo.

Neste sentido, compreende-se que o neorrealismo, ao nível da linguagem e do jogo poéticos, tenha reagido ao presencismo regressando ao pré-modernismo, jogando com os significados em detrimento dos significantes, mitigando a difícil articulação do modo poético com o seu fim social $^{27}$.

Deste modo, o enredo do poema Terra (com efeito, são vários poemas interligados que constituem, na realidade, um só) é contado (mais do que cantado) com recurso a alguns símbolos que, por analogia ou proximidade, sugerem uma perspetiva socioeconómica que,

\footnotetext{
25 Alguns neorrealistas requeriam da arte a fidelidade absoluta à realidade, mostrando-a refletida num espelho da sua dimensão; outros destacavam a importância do trabalho artístico, sendo a árvore o símbolo (cf. PITA, 2002, p. 230-241).

26 Esta questão não era exclusiva da jovem geração neorrealista portuguesa. Brecht e Lukács, com afinidades ao nível do sistema ideológico, estiveram em desacordo por motivos semelhantes: para Brecht - que destacava os aspetos estéticos -, o realismo socialista insistia num conteúdo socialista através de uma forma burguesa; Lukács - que enfatizava o conteúdo - rejeitava as vanguardas estéticas, optando pelas formas consagradas, por razões pragmáticas (cf. REIS, 1983, p. 392-395).

27 Eduardo Lourenço reconhece na poesia neorrealista portuguesa algo semelhante ao que Brecht criticava no realismo socialista, aludindo ao facto de aquela pertencer ao universo clássico da nossa poesia e não às nossas vanguardas literárias: "o mundo enquanto ordem (ou desordem) social é posto em questão, mas não a linguagem através da qual a contestação tem lugar” (1983: 209).
} 
verdadeiramente, ultrapassa a realidade concreta apresentada, embora seja esta, naturalmente, a potenciar a extração daquela. Para os neorrealistas, o símbolo será um recurso através do qual se tenderá a procurar demonstrar a essência das realidades concretas apresentadas; será uma forma (também de evitar a censura, não podemos esquecer), sobretudo, do real concreto apresentado se aproximar da universalidade de determinadas ideias.

Em Terra, encontram-se alguns símbolos que possuem potencialidades significativas análogas às que possuirão noutras obras neorrealistas. A madrugada (poemas 8 e 23) sugere a chegada do novo dia, o dia socialista ${ }^{28}$. A Primavera (poema 19) veicula também significações semelhantes, de índole revolucionária ${ }^{29}$. O comboio (poema 14) sugere o progresso e o desenvolvimento industrializado - não sendo, contudo, associado a um mundo perfeito, porque as injustiças continuam mesmo onde o comboio já chegou ${ }^{30}$.

O sino, com presença frequente (poemas: 1, 4, 11, 16, 17, 19, 20 e 24) e muitas vezes associado a um poder criador, não parece ter um sentido unívoco. A oscilação é, aliás, significativa. No poema 1, ouve-se o som místico do sino da igreja. No poema 4, o poeta nega ser esse badalão! o seu $\operatorname{sino}^{31}$. No poema 16, o badalão! já é um "pálido chamado" só ouvido pelo "vento perdido na serra". No poema 17, o badalão! surge de novo associado à festa popular de cariz religioso. No poema 19, surge, novamente, “o som clarificado do sino", associado à Primavera que parece querer chegar. No poema 20, ouve-se de novo o sino religioso. No último poema, o sino entoa a mudança $a^{32}$. Parece-nos poder compreender-se um balancear de um sino, ora místico e relacionado com o Céu, ora de um som claro que chama (será este o sino do poeta) e anuncia a mudança. No final, aquando do embarque de António (para a emigração), ouve-se o sino na terra.

O vento, a dimensão ativa do ar, é associado frequentemente ao alento e ao espírito; reserva-se-lhe por vezes o papel fecundador e renovador da vida. Nestes poemas, surge recorrentemente: no poema 6: "assobia o vento no monte, varrido"; no poema 9: "Se o vento dorme, / quem soprará as velas do moinho? (...) Se o vento dorme, / quem buscará as nuvens de longe?”; no poema 16: “Quem ouve o pálido chamado? / Ai só o vento perdido na serra!”; no poema 19: "Eis a Primavera no ventre fecundo da terra, / no teu seio, no teu sexo, / na tua boca entreaberta / para o hálito estranho trazido pelo vento. Sorri, Cassilda: hoje começa a vida"; no

\footnotetext{
28 "Vem, Cassilda, olhar a madrugada que rompe". (NAMORA, 1990a, p. 184).

29 "Olha a Primavera soltando os seus cabelos, / abrindo-te os braços e para o clarão das papoilas" (NAMORA, 1990a, p. 196).

30 “Os que vão às ceifas já viram o comboio (...) Eles não contam a fome nas ceifas, / não dizem do sol abrasando a carne / pelas campinas nuas e lânguidas. (...) Já viram o comboio, / já embarcaram no comboio, / Já viram mundo!” (NAMORA, 1990a, p. 191).

31 "António era menino, a casa era pobre, / foi servir senhores. / António teve uma irmã ovelha, / um cordeirinho filho; o rebanho era família! / Cresceu entre olhares e campos estranhos, estranhos ... / Badalão! badalão! - esta não é a voz do meu sino. / Mas todo o dia cantava pelo monte" (NAMORA, 1990a, p. 180).

32 "É preciso embarcar! / Badalão! badalão - o sino / já chora a despedida" (NAMORA, 1990a, p. 201).
} 
poema 24: "o vento anda como doido - levará o azeite; / a chuva desaba noite e dia - inundará tudo". Ainda que, como no último poema, ele pareça possuidor de um aspeto maléfico, o vento é sobretudo fecundador e renovador, associado por vezes ao monte e ao longe de onde podem vir novas para "o povo debruçado sobre os céus" (poema 9).

Imagem recorrente na obra de Namora ${ }^{33}$, a noite surge, neste livro, em diversos poemas (4, 5 e 13). Se a noite, no poema 5, é o tempo da clandestinidade e da preparação do amanhã, no poema 13, ela parece ser mais um tempo de obscuridade, de passividade e inconsciência. Na reedição de 1959, o poeta introduz-lhe o "velho Vicente" e, no meio da noite, surge uma "estrela do oriente", na qual ninguém parece reparar, exceto o velho, o único que não dorme: "Veio a noite e passou uma estrela, / - mas quem nela reparou? / Era uma estrela do oriente. / Repara nela, ao menos tu repara nela, Ti Vicente! / Repara nela, na sua mágoa de fogo, / para que alguém nesta aldeia / não a deixe seguir só”. O poeta reserva a esta estrela uma função semelhante à que os neorrealistas pareciam reservar para intelectuais e escritores: um fogo na noite escura. Vista como uma alteridade - absoluta ou relativa - que, interrompendo-os, liga dois momentos com afinidades de um mesmo processo, a noite, de algum modo, pode sugerir o momento histórico, em que o povo inteiro dorme, perspetivado dialeticamente.

A linguagem é, pois, significativamente metafórica. Na realidade, se o objetivo de uma comunicabilidade eficiente e unívoca se impusesse e se os poetas procurassem apenas meios facilmente descodificáveis intelectualmente e sem qualquer multiplicidade de potencialidades, a poesia perderia interesse estético, não pelas imagens apresentadas mas pelos meios linguísticos usados. O realismo caracteriza-se pela representação da realidade reconhecível como tal, mas não necessariamente por uma linguagem unívoca, sem quaisquer potencialidades simbólicas e apenas reconhecível intelectualmente. Neste sentido, não parece fundamentada a recusa de uma poesia realista ${ }^{34}$, quando não se quer virar as costas à realidade social e se privilegiam sistemas com potencialidade simbólica de representação objetiva dessa mesma realidade.

6. A teoria e a praxis neorrealistas recusaram limitar a conceção de poesia a mero idealismo, a puro subjetivismo e à exclusiva expressão da interioridade do poeta. Não subscreviam totalmente a conceção hegeliana de poesia, segundo a qual: "a (poesia lírica) tem por conteúdo o subjetivismo, o mundo interior, a alma agitada por sentimentos, alma que, em vez de agir, persiste na sua interioridade e não pode por consequência ter por forma e por fim senão a expansão do sujeito, a sua expressão. (...) É a interioridade que deve animar a exposição". (HEGEL, 1964, p. 158). Procuraram, por isso, imbuir a poesia de mais exterioridade, objetividade e realismo, estética pela qual optaram globalmente os escritores marxistas que

33 Em Namora, este tópico da zona escura, onde por vezes se vê uma luz, é uma imagem recorrente, nomeadamente em títulos - Fogo na Noite Escura, A Noite e a Madrugada, As Frias Madrugadas - e aberturas ou finais de capítulos e livros.

34 Não julgamos, de facto, paradoxal a expressão "poesia realista", contrariando, de algum modo, o que parecia considerar, por exemplo, João Pedro de Andrade nos anos 40 (1943, p. 55). 
quiseram expressar literariamente a sua mundividência. No fundo, para além da expressão do sujeito, o realismo social perspetivou os efeitos comunicativos, tanto no que concerne à transmissão de conhecimento, como nos sentimentos suscitados pela adesão a uma ideologia.

Com efeito, não vislumbravam qualquer incompatibilidade entre literatura e compromisso: defendia-se que o "eu" individual e "eu" social poderiam coexistir na obra literária. A sua teorização apelava por isso para o recurso a características de representação dinâmica e dialética, criando-se obras empenhadas em cantar "a experiência humana no seu estado de progresso e de luta, em movimento para um alvo" (FERREIRA, 1946, p. 120). Invocavam-se os artistas apelando para a não obnubilação dos interesses sociais em detrimento de preocupações estéticas: “apenas lhes pedimos (aos artistas) Arte (...) interessada e concreta, despida de preconceitos estéticos e integrada na vida e comunhão com os homens" (BACELAR, 1947, p. 269). Pedia-se arte sobre todos e para todos, e não apenas para o ocioso deleite de alguns.

No entanto, terá de se reconhecer que algumas potencialidades da linguagem e da comunicação poéticas são subvalorizadas pelos poetas neorrealistas dos anos 40 , nomeadamente a motivação entre significante e significado. Se, na realidade, o lirismo nunca se mostrou alheio à motivação fónica, à eufonia e à euritmia, pois o prazer provocado pela musicalidade do poema é uma característica tradicional do género, a poesia modernista havia surgido ainda mais regulada por um regime de produção significante sugestiva. (CARLOS, 1997, p. 53). O neorrealismo sentiu necessidade de desvalorizar, de algum modo, o prazer estético em detrimento do efeito de consciencialização resultante da eficácia semântico-pragmática da comunicação poética.

No entanto, reconhecia-se que o que distinguia a poesia da prosa não era a temática abordada, mas a sua formulação ${ }^{35}$. Daí que os poetas neorrealistas preocupados com a qualidade estética das obras não sentissem que tinham de abandonar a perspetiva social e humana, mas confrontavam-se com o desafio de a conciliar com os processos poéticos de comunicação próprios da poesia lírica.

A intensidade e a emoção poéticas não deveriam anular o desejo de pragmatismo da poesia. Ainda que se reconheça que por trás da poesia se encontra a convicção de que ela, como a arte em geral, poderia contribuir, indiretamente, para transformar uma sociedade decadente e injusta ${ }^{36}$, nos poemas surge "a nobreza, a seriedade, a gravidade, a beleza mesmo, um patetismo ou uma veemência líricas que nos tocam” (LOURENÇO, 1983, p. 210).

Em suma, a problemática da poesia neorrealista centra-se sobretudo na previsibilidade dos efeitos no leitor. Neste aspeto, não se diferencia do Modernismo. Na poesia, em geral,

\footnotetext{
35 Neste sentido, diz Mário Dionísio: "não é esta ou aquela ideia que inutilizou um poema, mas a maneira por que se A formulou" (1943, p. 263).

36 Fernando Namora colocou em Fogo na Noite Escura uma caricatura do poeta a que a sua geração se opunha: Carlos Nóbrega, no início do romance, era o artista solitário, boémio, excêntrico, efeminado, caprichoso, feito de renúncias, sem reação e que tendia a imitar os ricos, embora os criticasse (cf. 1988, p. 183-187).
} 
o que anima a exposição poética é um efeito da exterioridade na interioridade criadora. Esta procurará atribuir à composição poética potencialidades que possam aproximar o seu efeito no leitor do efeito que a realidade exterior teve no poeta ao o imbuir de um determinado estado. $\mathrm{O}$ caráter mais distintivo da poesia que constitui o Novo Cancioneiro assenta na expressão de uma mundividência e na verbalização de sentimentos resultantes do confronto desta com a realidade social existente. Emoção e conhecimento coexistem e contribuem para a mesma função.

No fundo, talvez a maior diferença em relação ao modernismo residisse no facto de Namora se ver eminentemente um ser social, produto e agente da sociedade, com os pés bem assentes na "terra". Com o seu livro, conciliando subjetividade e objetividade, indivíduo e coletivo, voz do poeta e voz dos homens (conquanto se sinta uma presença mais constante do segundo elemento destas dicotomias), Fernando Namora abriu caminho para uma poesia necessária, ainda que incompleta ${ }^{37}$, próxima da realidade do seu tempo e da amarga vida do povo na Terra. Identificando-se umas vezes com a árvore, outras vezes com o espelho, a poesia neorrealista acolheria, de algum modo, o exemplo poético, o sentimento humano e o olhar social de Fernando Namora, um escritor que estaria sempre na frente das constantes e renovadas partidas do mundo.

\section{Referências:}

ANDRADE, João Pedro. A Poesia da Moderníssima Geração - génese duma atitude poética. Porto: Liv. Latina, 1943.

BACELAR, Armando. “A arte e o público”, 2ª parte. Vértice, vol III, n 44, 1947.

BELCHIOR, Maria de Lurdes. "Poesia portuguesa contemporânea: a geração de 40". Os Homens e os Livros II. Lisboa: Verbo, 1980.

CARLOS, Luís Adriano. “A poesia portuguesa no século XX e o problema do seu ensino". Incidências, $\mathrm{n}^{0}$ 1. Lisboa: Colibri, 1997.

CHALENDAR, Pierrette \& Gérard. Temas e Estruturas na Obra de Fernando Namora. Lisboa: Moraes, 1979.

DIONÍSIO, Mário. “Antiprefácio”. Poesia Incompleta, 2a ed. Lisboa: Europa-América, s/d. . "Ficha 11”. Seara Nova, no 813. Lisboa: 1943, p.263.

. Autobiografia. Lisboa: O Jornal, 1987.

FERREIRA, Ana Paula. Alves Redol e o Neo-Realismo Português. Lisboa: Caminho, 1992.

37 Significativos poderão ser alguns títulos de volumes de poesia de poetas neorrealistas: Poesia Incompleta de Mário Dionísio ou A Poesia Necessária de Joaquim Namorado. 
FERREIRA, Armando Ventura. “A poesia de Manuel da Fonseca”. Seara Nova, n 984. Lisboa: 1946.

FERREIRA, José Gomes. A Memória das Palavras. Lisboa: Portugália, 1966.

FILIPE, Manuel. “Algumas notas para uma nova poética”. Sol Nascente, nº 10, Porto, 1937.

GOLDMANN. Pour une Sociologie du Roman. Paris: Gallimard, 1964.

Guimarães, Fernando. A Poesia da Presença e o Aparecimento do Neo-Realismo. Porto: Brasília Editora, 1981.

HEGEL. Estética VII - Poesia. Lisboa: Guimarães Editores, 1964.

LIMA, Manuel Campos. “O processo subjetivo no romance”. O Diabo, nº 179, 1938.

. "Das criaturas na vida quotidiana aos tipos na ficção literária". Vértice, no 166. Coimbra:1957, p. 353-355.

LOURENÇO, Eduardo. Sentido e Forma da Poesia Neo-Realista. Lisboa: Dom Quixote, 1983.

. "Presença ou a contra-revolução do modernismo português". O Tempo e a Poesia. Lisboa: Relógio d’Água, 1987.

LUKÁCS. Introdução a uma Estética Marxista. Rio de Janeiro: Civilização Brasileira, 1978.

MARTELO, Rosa Maria. A Construção do Mundo na Poesia de Carlos de Oliveira, Tese de Doutoramento. Porto: FLUP, 1996.

MONTEIRO, Adolfo Casais. O Romance e os Seus Problemas. Lisboa: Biblioteca de Cultura portuguesa, 1950.

MOURÃO-FERREIRA, David "Homenagem a Fernando Namora, cinquenta anos de literatura vivida". Colóquio/Letras, nº 103, 1988, p.16.

NAMORA, Fernando. "Fernando Namora e os novos pouco sérios". Seara Nova, n 734, 1941. . Fogo na Noite Escura, Mem Martins, Europa-América, 1988.

. “Terra”. Torres, A. Pinheiro (org). Novo Cancioneiro. Lisboa: Caminho, 1989.

. As Frias Madrugadas, Mem Martins, Europa-América, 1990a.

. "Prefácio". Casa da Malta, Mem Martins, Europa-América, 1990b. 
. Um Sino na Montanha. Mem Martins, Europa-América, 1991.

NAMORADO, Joaquim. "Fernando Namora, escritor ainda vivo". Obras, Ensaios e Críticas

- Poética da Cultura. Lisboa: Caminho, 1994.

PETROV, Petar. O Realismo na Ficção de José Cardoso Pires e Ruben Fonseca, Tese de Doutoramento, FLUL, Lisboa, 1996.

PITA, António Pedro. Conflito e Unidade no Neo-Realismo Português. Porto: Campo das Letras, 2002.

REIS, Carlos. O Discurso Ideológico do Neo-Realismo Português. Coimbra: Almedina, 1983.

RÉGIO, José. “Classicismo e modernismo”. Presença, n² 2, Coimbra, 1927, p.1-2.

RODRIGUES, Urbano Tavares. “Expressões do humanismo de Fernando Namora”. Colóquio/ Letras, $\mathrm{n}^{\mathrm{o}}$ 103, 1988, p.9.

SACRAMENTO, Mário. Há Uma Estética Neo-Realista?. Lisboa: Dom Quixote, 1968.

SALEMA, Álvaro. "Três reflexões sobre a obra de Fernando Namora". Tempo de Leitura. Lisboa: Moraes, 1981, p.149-154.

SIMÕES, João Gaspar. “Modernismo”. Presença, no 14-15, Coimbra, 1928, p.3. . "Fernando Namora". Crítica II, INCM, 1960.

SOARES, Rodrigo. Por um Novo Humanismo. Porto: Portugália, 1947.

TORRES, Alexandre Pinheiro (org.). Novo Cancioneiro. Lisboa: Caminho, 1989.

. O Movimento Neo-Realista em Portugal na Sua Primeira Fase. Lisboa: ICP, 1977.

VASCONCELOS, Taborda de. Fernando Namora. Lisboa: Arcádia, 1972. 